\title{
AN IMPACT OF THE EFFICIENT FUNCTIONING OF THE VENTILATION AND AIR-CONDITIONING SYSTEM ON THERMAL COMFORT OF THE MEDICAL STAFF IN THE OPERATING ROOM
}

\author{
Tomasz Jankowski', Magdalena Młynarczyk²
}

1 Department of Chemical, Aerosols and Biological Hazards, Laboratory of Aerosols, Filtration and Ventilation, Central Institute for Labour Protection - National Research Institute, Czerniakowska 16, 00-701 Warsaw, Poland, e-mail: tojan@ciop.pl

2 Department of Ergonomics, Laboratory of Thermal Loads, Central Institute for Labour Protection - National Research Institute, Czerniakowska 16, 00-701 Warsaw, Poland, e-mail: mazwo@ciop.pl

Received: 2016.08.11 Accepted: 2016.09.26 Published: 2016.11.01

\begin{abstract}
Ventilation and air conditioning systems are necessary for developing proper parameters of indoor environment in operating rooms. The main task of ventilation and air conditioning in those specific areas consists in creating desirable temperature, reducing the number of microorganisms and the concentrations of hazardous gases and substances in the air, as well as ensuring the proper direction of airflow. In Poland, indoor environment in operating rooms has to comply with the requirements set out in three regulations (Journal of Laws of 2002 No. 75, item 690, as amended, Journal of Laws of 2002 No. 217, item 1833, Journal of Laws of 2011 No. 31, item 158, as amended) and the document entitled "Guidelines for the design of general hospitals". Given insufficient accuracy of the abovementioned national documents, it is a common practice to use foreign standards, i.e. ASHRAE Standard 170-2013, DIN 1946-4: 2008 and FprCEN TR 16244: 2011. When considering the conditions for thermal comfort, it is important to bear in mind a close link between air flow velocity and air temperature. Air in the zone occupied by patients and medical staff must not cause the sensation of draft. Furthermore, air velocity should be sufficient to eliminate interference caused by the presence of people and other sources of heat. It should also reduce the turbulence level in the air in the operating room. Efficient functioning of ventilation and air conditioning was tested during treatments and operations carried out on three wards of a Warsaw hospital. Tests were performed with the participation of medical staff from various surgical units. They were asked to perform minor manual tasks to simulate work on the operating table, and to complete a questionnaire on subjective thermal sensation. The applied methodology is widely used during testing of general and local ventilation in public buildings. Air temperature, relative humidity, air flow supply and exhaust air from the operating room were determined on the basis of VelociCalc 8360 and Testo 435 anemometers with a 3 -function probe and 3 vane probes with the diameter of $16 \mathrm{~mm}, 60 \mathrm{~mm}$ and $100 \mathrm{~mm}$. Throughout the study, microclimate conditions in the operating rooms were controlled by the EHA MM101 microclimate meter. Test results showed that the microclimate parameters met the requirements of the aforementioned documents. However, individual thermal sensations reported by the medical staff pointed to the lack of thermal comfort and, in extreme cases, e.g. when using lead aprons during operations, perception of the thermal environment as 'very hot'. The efficiency and type of air distribution in operating rooms has a decisive effect on the results.
\end{abstract}

Keywords: ventilation, air velocity, microclimate, operating room, hospital 


\section{INTRODUCTION}

Air-conditioning and ventilation systems are necessary for creating proper parameters of indoor environment in hospital operating rooms. The main task of air-conditioning and ventilation systems in those specific areas consists in creating desirable temperature, reducing the number of microorganisms and the concentrations of hazardous gases and substances in the air, as well as ensuring the proper direction of airflow [Różycki 2013].

In Poland indoor environment of the operating room has to comply with the requirements set out in three regulations [Journal of Laws of 2002 No. 75, item 690, as amended, Journal of Laws of 2002 No. 217, item 1833, Journal of Laws of 2011 No. 31, item 158, as amended], and the document entitled "Guidelines for the design of general hospitals". Given insufficient accuracy of the above-mentioned national documents, it is a common practice to use the foreign standards, i.e. ASHRAE Standard 170-2013, DIN 1946-4: 2008 and FprCEN TR 16244: 2011.

The task of creating microclimate in hospital rooms, in comparison to other types of facilities, is distinguished by a significant degree of difficulty. Given critical importance of rigorous cleanliness and hygiene in healthcare settings, indoor air quality in operating rooms is undoubtedly an important goal for air-conditioning and ventilation engineers [Uścinowicz 2015].

The microclimate of operating rooms is not only limited to ensuring proper conditions for thermal comfort but, first and foremost, it involves establishing and maintaining zones of controlled cleanliness [Charkowska 2012]. The key microclimate parameters determining thermal comfort include: indoor air temperature, humidity, airflow velocity. In contrast to air temperature and airflow velocity, an impact of humidity on the occupant's satisfaction with the surrounding thermal conditions is marginal because a human is able to acclimatise to a wider range of temperatures [Zwolińska 2012]. Fluctuations of humidity in the range of $30-70 \%$ are acceptable. The specificity of operating rooms equipped with the air-conditioning and ventilation system requires reducing the range of air humidity. The automatic control system controls air-conditioning and ventilation to ensure ca. $50 \%$ humidity in the operating room with the indoor temperature at $20^{\circ} \mathrm{C}$.
It is therefore important to assess the effect of room air distribution on air parameters in the zone of direct impact on the patient and near the operating table, taking into particular consideration the breathing zone of medical personnel.

\section{MATERIALS AND METHODS}

Tests of indoor air parameters were performed with the 435-2 TESTO measuring set. They included measurements of air velocity, temperature and relative humidity. The set together with a 3 -function probe and 3 vane probes with the diameter of $16 \mathrm{~mm}, 60 \mathrm{~mm}$ and $100 \mathrm{~mm}$ (Testo AG, Germany) (Figure 1) allows measurement of air velocity, temperature and relative humidity in the following ranges:

- air velocity: $0 \div 20 \mathrm{~m} / \mathrm{s}$,

- air temperature: $-20 \div 70{ }^{\circ} \mathrm{C}$,

- relative humidity: $0 \div 100 \% \mathrm{RH}$.

The anemometer is a one-way type with directional sensitivity of $\pm 20^{\circ}$. This device may be used in ventilation ducts and at the workstations. The time constant for an anemometer is less than $0.5 \mathrm{~s}$. Uncertainty of individual measurement does not exceed $0.02 \mathrm{~m} / \mathrm{s}+5 \%$ reading in the

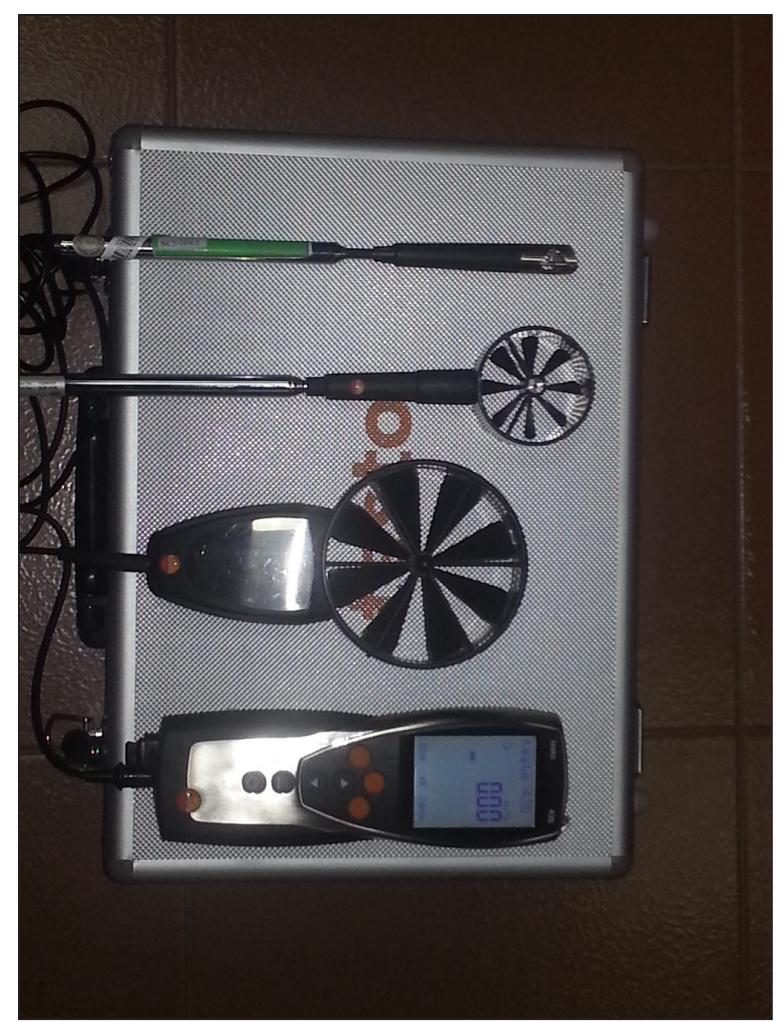

Figure. 1. A view of the Testo experimental set 
range between $0.2 \mathrm{~m} / \mathrm{s}$ and $1.0 \mathrm{~m} / \mathrm{s}$. Anemometer inputs were recorded for analysis.

The probes of the device were placed in measuring points, on a specially constructed mobile supporting structure, thus enabling measurements in different locations of the room (Figure 2). The system efficiency was tested on a Warsaw hospital ward. Tests were conducted with the participation of medical staff who performed minor manual tasks to simulate work at the operating table. Given the specificity of surgical procedures, the operating room was equipped with, amongst others, X-ray tubes, which in the opinion of the medical personnel were the main source of heat and noise. The operating room had a one-way air conditioning and ventilation system (Figure 2). The zone surrounding an operating table did not have a laminar ceiling.

The medical personnel wore surgical clothing and aprons for the tests. Given that the operating room was also used for surgical operations without the need of a lead apron, such variant was developed, as well. Three members of the medical personnel participated in the tests performed in the operating room i.e. a surgeon assistant, a scrub nurse and a technician handling the equipment.

The measurements were made with a thermal anemometer. Its probes were placed in the middle of each of the measuring point and the sensor was located so as to make measuring direction perpendicular to the interior of a measuring plane (the measurement displayed the maximum air velocity). Interference at the sensor counter current (air movement caused by the presence of personnel, equipment, etc.) was reduced to the minimum during measurements. Individual velocities $\mathrm{V}_{i}$ perpendicular to the interior of a measuring plane were measured and recorded at regular intervals, i.e. every 1.0 second or more frequently, at least for 60 seconds. For each measuring point mean values $\mathrm{V}_{\mathrm{s} r \mathrm{n}}$ of measured constituents of air velocity $V_{i, n}[\mathrm{~m} / \mathrm{s}]$ were calculated on the basis of the following equation:

$$
V_{\dot{s} r, n}=\frac{1}{n} \sum_{i=1}^{n} V_{i, n}
$$

where: $V_{i, n}$ - temporary constituent of air velocity in the ' $\mathrm{n}$ ' measuring point $[\mathrm{m} / \mathrm{s}]$,

$n$ - the number of measurements made in the period of 60 seconds.

The measurements defined air temperature distribution $\mathrm{T}\left[{ }^{\circ} \mathrm{C}\right]$ and relative humidity $\mathrm{RH}[\%]$ in each measuring point of local airflow velocity.

In order to determine the influence of changes in the ventilation and air conditioning system on the parameters related to air distribution in the working space of the medical staff, three ventilation variants were used. Different values of supplied air volume served as a variable input parameter for the system. In the measurements three values of airflow were used, which corresponded to 25,50 and $75 \%$ of the maximum value.

The variant with and without the tubular adsorber with silica gel was used as a variable parameter for the air-conditioning system.

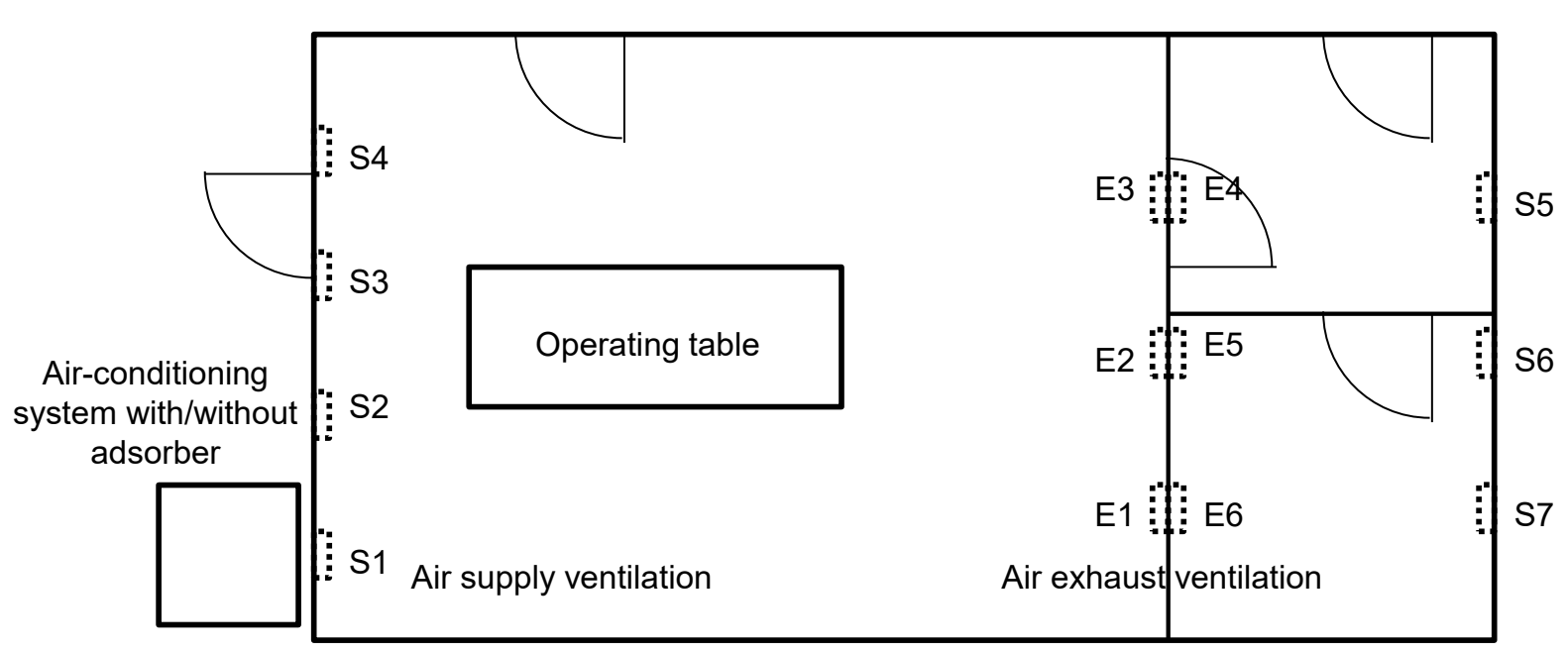

Figure 2. Scheme of the operating room including the location of air conditioning and ventilation system ( $\mathrm{S}$ supply, E exhaust) 


\section{RESULTS}

Figures 3, 4 and 5 show changes of local airflow velocity, temperature and relative humidity in the working area of medical personnel, according to the ventilation variant.

From the data analysis shown in Figures $3 \div 5$, it transpires that changes in the air volume cause a change of air parameters in the operating room. A $50 \%$ increase in low enabled shaping air parameters in the following manner:

- increase of air velocity from 0.76 to $1.73 \mathrm{~m} / \mathrm{s}$,

- increase of air temperature from 23.70 to $26.98^{\circ} \mathrm{C}$,

- decrease of relative humidity from 34.05 to $24.54 \%$ RH.

It was furthermore observed that air parameters were not stable. The bigger the air volume was

- the bigger fluctuations of air velocity, ranging between 0.12 and $0.16 \mathrm{~m} / \mathrm{s}$

- the smaller fluctuations of air temperature, ranging between 0.63 and $0.26^{\circ} \mathrm{C}$ and relative humidity, between 2.60 and $0.71 \% \mathrm{RH}$.

Figures 6,7 and 8 show changes in air velocity, temperature and relative humidity at different distances from air supply ventilation in the operating room.

Measurements of air parameters in different zones of the operating room revealed that a work cycle of the cooling unit in the air conditioning system had no influence on fluctuations of air velocity and temperature in given measuring points.

Air velocity at the breathing zone of the medical staff did not exceed design values of $0.5 \mathrm{~m} / \mathrm{s}$ and ranged between 0.1 and $0.4 \mathrm{~m} / \mathrm{s}$.

Fluctuations of relative humidity occurred in all three measuring points. The moment power was supplied to the cooling unit air humidity dropped, whereas when the unit was automatically switched off air humidity increased. The bigger the distance from the front panel of air supplier the smaller the range in air humidity fluctuations:

- outlet of the air supplier - from $25.67 \%$ to $79.41 \%$

- the mid-point of the room - from $32.86 \%$ to $45.65 \%$

- human breathing zone - from $33.67 \%$ to $40.24 \%$.

The use of a tubular adsorber in ventilation ducks and air conditioners of the operating room stabilised all air parameters in the direct

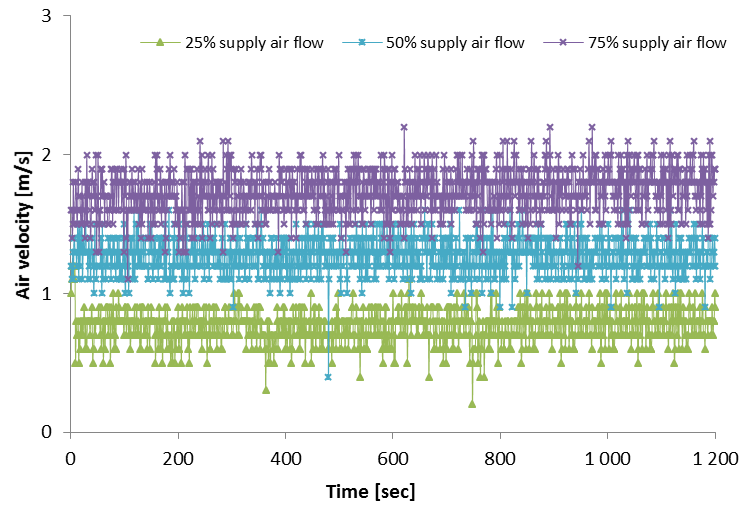

Figure 3. Changes of air velocity in the operating room using various ventilation settings

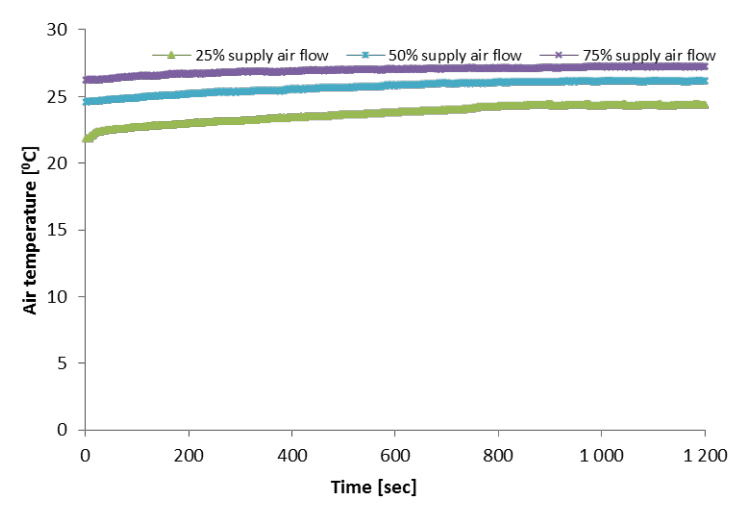

Figure 4. Changes of air temperature in the operating room using various ventilation settings

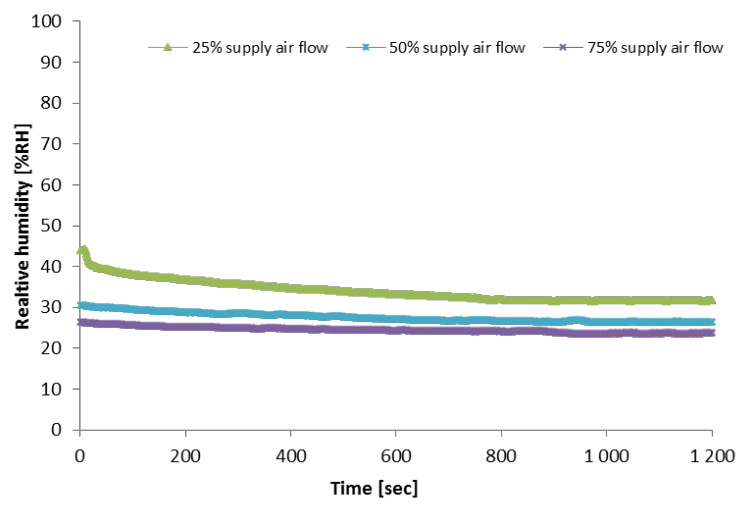

Figure 5. Changes of relative air humidity in the operating room using various ventilation settings

air supply zone and in the breathing zone of the medical staff. The geometry of openings in air suppliers allowed reaching linear air velocity at their outlets in the range up to $2 \mathrm{~m} / \mathrm{s}$. Air temperature could be smoothly adjusted between 10 and $25^{\circ} \mathrm{C}$. It was furthermore found that relative humidity did not exceed $50 \%$ when the device was in use (Figure 9). 


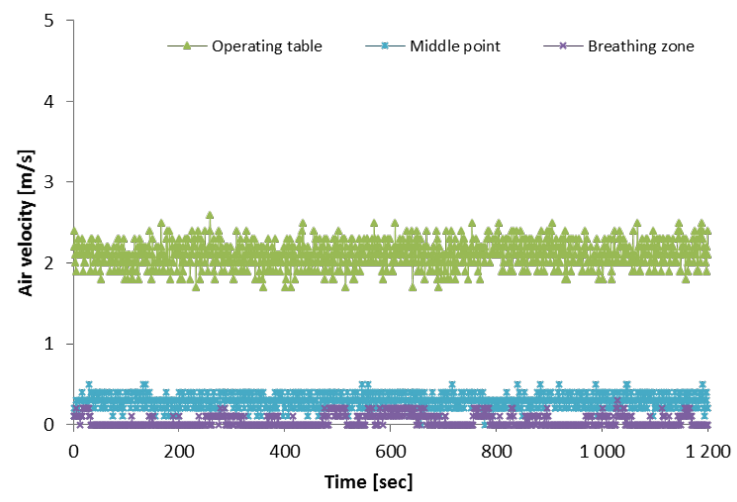

Figure 6. Changes of air velocity at different distances from air supply ventilation

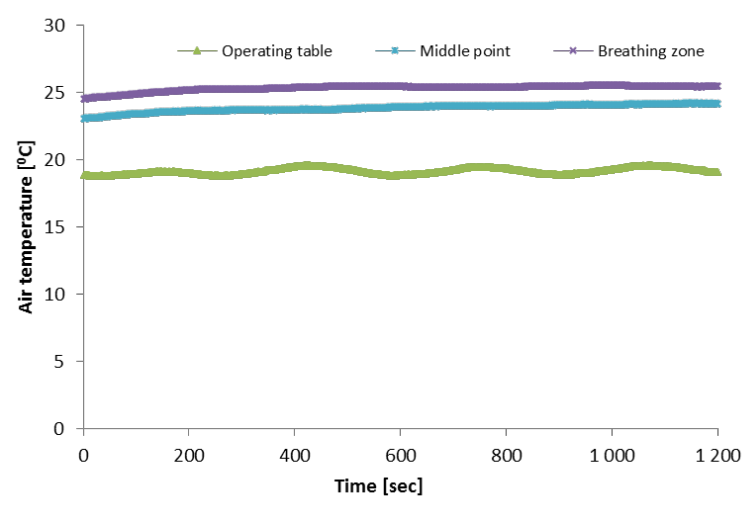

Figure 7. Changes of air temperature at different distances from air supply ventilation

\section{CONCLUSIONS}

An analysis of the results showed that the choice of a ventilation variant in an operating room had a significant influence on the parameters of thermal comfort of medical personnel.

Microclimate parameters in the hospital operating room satisfied the requirements set out in normative documents. The efficiency and type of air distribution had a decisive effect on such results.

Anemometric measurements of airflows are of considerable importance for research on air distribution in an operating room. The said methods allow depicting and defining the role of parameters characteristics for thermal comfort sensation of personnel in the zone of direct impact on the patient and near the operating table, taking into particular consideration the breathing zone of the medical staff.

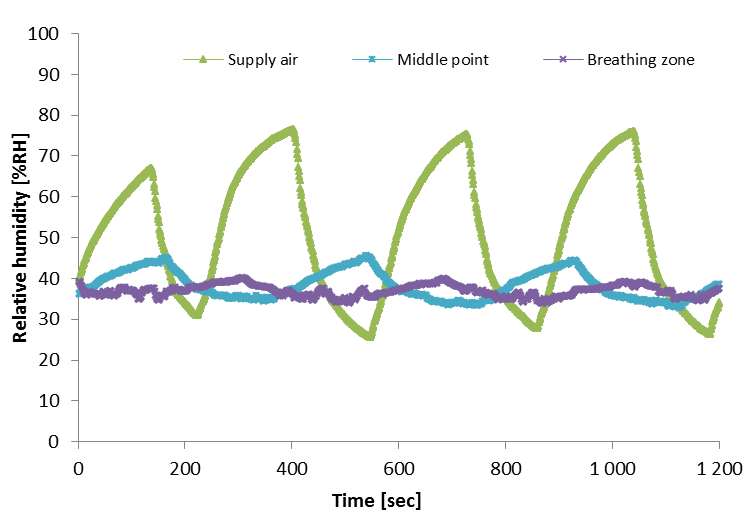

Figure 8. Changes of relative air humidity at different distances from air supply ventilation

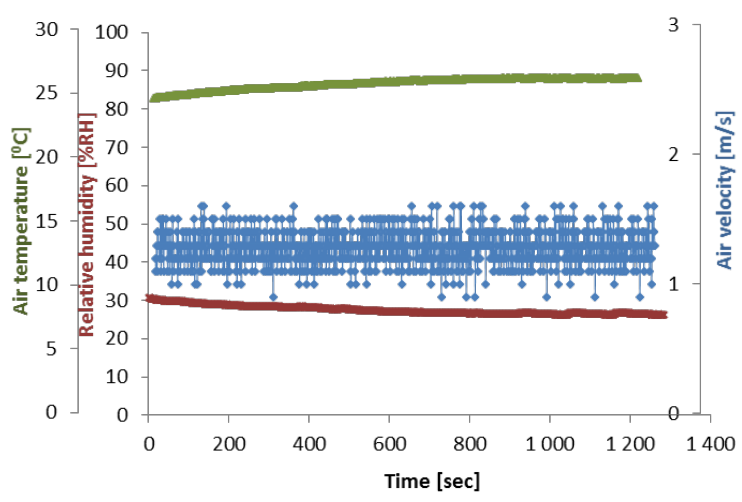

Figure 9. Changes in air temperature, relative humidity and velocity in the operating room equipped in the air conditioning system with the tubular adsorber

By defining the aforesaid dependencies an observer is able to determine an influence of particular local factors and assess the correctness of the applied concept of air distribution, bearing in mind different specifities of medical treatments and surgical operations.

\section{Acknowledgements}

This publication was developed on the basis of the results of the project no. III.P.08 carried out in the framework of the 3rd stage of multiannual programme "Improvement of safety and working conditions" co-financed in the years 2014-2016 by the Ministry of Science and Higher Education in the area of research and development work. Main performer: CIOP-PIB. 


\section{REFERENCES}

1. ASHRAE Standard 170-2013. Ventilation of health care facilities, ASHRAE.

2. Charkowska A. 2012. Klimatyzacja szpitali w dokumentach prawnych - teraźniejszość i przyszłość. Chłodnictwo i Klimatyzacja, 11, 38-44.

3. DIN 1946-4:2008. Ventilation and air conditioning - Part 4: VAC systems in buildings and rooms used in the health care sector, DIN.

4. FprCEN TR 16244:2011(E). Ventilation for hospitals, CEN.

5. Journal of Laws of 2002 No. 75, item 690, as amended: Rozporządzenie Ministra Infrastruktury z dnia 12 kwietnia 2002 r. w sprawie warunków technicznych, jakim powinny odpowiadać budynki i ich usytuowanie, wraz z późniejszymi zmianami.

6. Journal of Laws of 2002 No. 217, item 1833. Rozporządzenie Ministra Pracy i Polityki Społecznej z dnia 29 listopada 2002 r. w sprawie najwyższych dopuszczalnych stężeń i natężeń czynników szko- dliwych dla zdrowia w środowisku pracy.

7. Journal of Laws of 2011 No. 31, item 158, as amended. Rozporządzenie Ministra Zdrowia Z dnia 2 lutego 2011 r. w sprawie wymagań, jakim powinny odpowiadać pod względem fachowym i sanitarnym pomieszczenia i urządzenia zakładu opieki zdrowotnej, wraz z późniejszymi zmianami.

8. Kruczkowski P. 1984. Wytyczne projektowania szpitali ogólnych. Instalacje sanitarne. Zeszyt 5 Wentylacja i Klimatyzacja, Ministerstwo Zdrowia i Opieki Społecznej.

9. Różycki A. 2013. Czystość, bezpieczeństwo i ekonomia sal operacyjnych w standardach europejskich, Infrastruktura techniczna szpitala, 1, 43-50.

10. Uścinowicz P., Chludzińska M., Bogdan A. 2015. Thermal environment conditions in Polish operating rooms. Building and Environment, 94, 296-304.

11. Zwolińska M., Bogdan A. 2012. Impact of the medical clothing on the thermal stress of surgeons. Applied Ergonomics, 43, 1096-1104. 